\title{
Cellular Composition of the Human Diabetic Pancreas
}

\author{
J.Rahier, R. M.Goebbels and J.C.Henquin \\ Department of Pathology and Unité de Diabète et Croissance, University of Louvain School of Medicine, Brussels, Belgium
}

Summary. Insulin, glucagon, somatostatin and pancreatic polypeptide cells were stained by immunoperoxidase techniques and quantitated morphometrically in sections of pancreases obtained from eight control subjects, four Type 1 (insulin-dependent) and eight Type 2 (non-insulin-dependent) diabetic patients. The whole pancreas was studied to take into consideration the heterogeneous distribution of the different cell types. From the volume density of each cell type, and the weight of each lobe of the pancreas, the total mass of endocrine tissue was calculated. It averaged $1395 \mathrm{mg}$ in control subjects, $413 \mathrm{mg}$ in Type 1 and $1449 \mathrm{mg}$ in Type 2 diabetic patients. The loss of endocrine tissue observed in the Type 1 patients was almost restricted to the lobe poor in pancreatic polypeptide cells. In these patients, B cells were practically absent (at the most seven per section), but the 'atrophic islets" still contained numerous $\mathrm{A}, \mathrm{D}$, or pancreatic polypeptide cells. The mass of A, D and pancreatic polypeptide cells and the ratio of $\mathrm{D}$ to $\mathrm{A}$ cells were not different from those measured in the control subjects. This shows that the disappearance of B cells in Type 1 diabetes has no preferential effect on any other endocrine cell of the pancreas. In Type 2 diabetes, the mass of A cells was increased, whereas that of B, D and pancreatic polypeptide cells was not changed. This hyperplasia of A cells leads to a decrease in the ratio of $B$ to $A$ and of $D$ to $A$ cells. These alterations may enlighten certain aspects of the physiopathology of Type 2 diabetes.

Key words: Types 1 and 2 diabetes, immunocytochemistry, morphometry, human pancreas
The pathology of the endocrine pancreas in human diabetes mellitus has long received much attention [1-7]. However, our current knowledge, reviewed recently [8, 9] essentially remains based on studies of small specimens of the pancreas stained with histochemical methods. More sensitive and more specific immunocytochemical techniques were used in only three studies of fragments of pancreas obtained from Type 1 (insulindependent) diabetic patients [10-12].

The present work is a quantitative study of the cytologic composition of the endocrine pancreas in normal subjects, and in Type 1 (insulin-dependent) and Type 2 (non-insulin-dependent) diabetic patients. The entire pancreas was studied in order to take into account the heterogeneous distribution of the different cell types [13-15] and the preferential atrophy of the region poor in pancreatic polypeptide (PP) cells in Type 1 diabetes [16]. Furthermore, this approach makes it possible to evaluate the changes in the total mass of each endocrine cell type.

\section{Materials and Methods}

Pancreases were obtained within $6 \mathrm{~h}$ after death, at the autopsies of four Type 1, eight Type 2 diabetic patients and eight age-matched control subjects. Four of these control subjects were healthy individuals killed in road traffic accidents and the other four died from diseases not known to affect the endocrine pancreas. Their fasting blood glucose levels were normal. Clinical data concerning the diabetic patients are given in Table 1 . The four subjects with Type 1 diabetes had a typical clinical story and required insulin treatment; one of them had also taken quinine for 15 years. C-peptide was measured in three of these patients and was below the minimal detectable level. In the eight diabetic patients with Type 2 diabetes, fasting blood glucose was $>$ $8.5 \mathrm{mmol} / 1$ on several occasions. In four of them, diagnosis of diabetes was made only a few days or weeks before death. Three received insulin treatment although, in at least two of them, C-peptide levels were normal.

After careful dissection, the whole pancreas was cut in parallel slices $2-3 \mathrm{~mm}$ thick. All slices were numbered, weighed, fixed in Bouin-Allen's fluid and embedded in paraffin. The limits of the lobe rich in pancreatic polypeptide (PP) cells $[14,15]$ were delineated as follows: from each slice of the cephalic and isthmic regions, a $5-\mu \mathrm{m}$ section was stained by the peroxidase-antiperoxidase (PAP) tech- 
Table 1. Characteristics of the control and diabetic patients

\begin{tabular}{|c|c|c|c|c|c|c|c|}
\hline & \multirow{2}{*}{$\begin{array}{l}\text { Age } \\
\text { (years) }\end{array}$} & \multirow[t]{2}{*}{$\operatorname{Sex}$} & \multirow{2}{*}{$\begin{array}{l}\text { Duration of } \\
\text { diabetes } \\
\text { (years) }\end{array}$} & \multirow{2}{*}{$\begin{array}{l}\text { Plasma } \\
\text { C-peptide } \\
(\mathrm{pmol} / \mathrm{ml})\end{array}$} & \multirow[t]{2}{*}{ Treatment } & \multicolumn{2}{|c|}{ Weight of pancreas } \\
\hline & & & & & & Total (g) & $\begin{array}{l}\text { Lobe rich in } \\
\text { PP-cells (\%) }\end{array}$ \\
\hline Control subjects $(\mathrm{n}=8)$ & $\begin{array}{l}54 \\
(18-86)\end{array}$ & $\begin{array}{l}4 \mathrm{M} \\
4 \mathrm{~F}\end{array}$ & - & - & - & $\begin{array}{l}82 \\
(67-110)\end{array}$ & $\begin{array}{l}11.1 \\
(6.9-17.4)\end{array}$ \\
\hline Type 1 diabetic patients & $\begin{array}{l}16 \\
37 \\
49 \\
60\end{array}$ & $\begin{array}{l}\mathrm{F} \\
\mathrm{M} \\
\mathrm{M} \\
\mathrm{M}\end{array}$ & $\begin{array}{l}1.5 \\
25 \\
34 \\
14\end{array}$ & $\begin{array}{l}0.03^{\mathrm{a}} \\
0.03 \\
- \\
0.05\end{array}$ & $\begin{array}{l}\text { Insulin } \\
\text { Insulin } \\
\text { Insulin + sulphonylurea } \\
\text { Insulin + quinine }\end{array}$ & $\begin{array}{l}39 \\
26 \\
43 \\
51\end{array}$ & $\begin{array}{l}17.6 \\
26.5 \\
16.5 \\
21.9\end{array}$ \\
\hline Type 2 diabetic patients & $\begin{array}{l}55 \\
58 \\
59 \\
64 \\
65 \\
67 \\
73 \\
75\end{array}$ & $\begin{array}{l}M \\
M \\
F \\
F \\
M \\
F \\
F \\
F\end{array}$ & $\begin{array}{c}7 \\
10 \\
6 \\
? \mathrm{~b} \\
? \\
? \\
12 \\
?\end{array}$ & $\begin{array}{l}- \\
0.15 \\
1.10 \\
- \\
- \\
- \\
1.60 \\
-\end{array}$ & $\begin{array}{l}\text { Insulin } \\
\text { Sulphonylurea } \\
\text { Insulin + sulphonylurea } \\
- \\
- \\
- \\
\text { Insulin + sulphonylurea } \\
-\end{array}$ & $\begin{array}{r}72 \\
88 \\
55 \\
80 \\
100 \\
63 \\
56 \\
72\end{array}$ & $\begin{array}{l}11.6 \\
14.2 \\
10.9 \\
12.1 \\
16.9 \\
14.6 \\
16.2 \\
11.6\end{array}$ \\
\hline
\end{tabular}

For control subjects, values are means with the ranges in parentheses. ${ }^{a}$ Non-specific plasma interference in the C-peptide assay is equivalent to $0.03-0.05 \mathrm{pmol} / \mathrm{ml}$. ${ }^{\mathrm{b}} \mathrm{In}$ four Type 2 diabetic patients, diagnosis of diabetes was made during the hospital admission which preceded death

nique of Sternberger [17], using an antiserum against bovine pancreatic polypeptide. The relative surface of the region rich in PP cells was measured by a semi-automatic image analyser (Videoplan, Kontron Bildanalyse, Eching, FRG). From these measurements and from the weight of each slice, the total weight of the two lobes, rich and poor in PP cells, was calculated.

Specimens were then taken in the posterior part of the head (lobe rich in PP cells), in the anterior part of the head, in the body and in the tail. From each of them, four consecutive sections were stained by the PAP technique with guinea-pig anti-insulin serum (Dr. P. H. Wright, Indianapolis), rabbit anti-glucagon serum (Dr. A. Like, Worcester, USA), rabbit anti-somatostatin serum (Dr. W. Gepts, Brussels) and rabbit anti-pancreatic polypeptide serum (Dr. R. E. Chance, Indianapolis) at dilutions of $1 / 3000,1 / 4000,1 / 10000$ and $1 / 40000$, respectively. The specificity of each reaction was assessed by absorption of the antiserum with the corresponding antigen.

The volume density of each endocrine cell type and of mesenchymal tissue was determined by the point counting method of Chalkley [18], as previously reported [19]. When the volume density of a cell type is low, its determination is fraught with a large error [19, 20]. Therefore, to increase accuracy, we measured the volume density of PP cells in the lobe poor in PP cells and of glucagon-cells in the lobe rich in PP cells by planimetry of all positive cells in a whole section. The same technique was also used for insulin-cells in the Type 1 diabetic patients. The volume density of each cell type is given relatively to the epithelial tissue, thus excluding mesenchymal tissue; this mode of expression avoids the influence of changes in mesenchymal tissue, such as fatty infiltration, on the volume density of the endocrine tissue. From the volume density of each cell type in the two lobes of the pancreas, the proportion of mesenchymal tissue and the absolute weight of these two lobes, the total mass of the different endocrine cells was calculated. Approximation of mass to volume appears justified by the lack of difference in the percentage of mesenchymal tissue in these three groups: $21.7 \pm 2.5 \%$ in control subjects; $28.1 \pm 5.3 \%$ in Type 1 diabetes; $25.0 \pm 1.9 \%$ in Type 2 diabetes (mean \pm SEM).

The proportions of $\mathrm{A}, \mathrm{B}$ and $\mathrm{D}$ cells outside the islets were determined as follows. In the Type 1 patients, all $B$ cells in a section were counted. For B cells in the control subjects and in the Type 2 patients, and for $A$ and D cells in the three groups, 500 nucleated cells were counted and their localization determined. For these measurements the sections were taken from the region poor in PP cells.

Results are presented as mean \pm SEM or with the range. The significance of differences between means was assessed by the Wilcoxon rank-sum test [21].

\section{Results}

The weight of the pancreas was severely reduced in Type 1 diabetes but, as previously reported [16], the atrophy was almost exclusively restricted to the lobe poor in PP cells. This resulted in an increase in the relative volume of the lobe rich in PP cells (Table 1). The weight of the pancreas was not significantly changed in Type 2 diabetes.

In the posterior part of the head (rich in PP cells), the volume density of total endocrine tissue was similar in the three groups of subjects (Fig. 1). In the anterior part of the head and in the rest of the pancreas, the volume density of endocrine cells was decreased in the Type 1 diabetic patients $(p<0.005)$, but it was not changed in the Type 2 diabetic patients compared with the control subjects. In normal subjects and in the Type 2 diabetic patients, the volume density of endocrine tissue was higher in the tail than in the anterior part of the head $(p<0.025)$. There was no difference in the Type 1 patients (Fig. 1).

The proportion of endocrine cells found outside the islets, in the region poor in PP cells, is given in Table 2. In three of the four cases of Type 1 diabetes, it was still possible to identify rare B cells (one to seven cells per slice); they were always isolated between acinar cells. The proportion of $\mathrm{A}$ cells present outside the islets tended to be higher than in the control subjects, but this was significant only for the small clusters. The percentage of isolated D cells was strikingly increased. By contrast, fewer A and D cells were found outside the islets in the Type 2 diabetic patients, but the difference was significant only for A cells in small clusters (Table 2).

In the region poor in PP cells, islets of control subjects displayed a regular architecture with a central core 
Table 2. Percentages of the different endocrine cells present outside the islets

\begin{tabular}{lccc}
\hline & \multicolumn{1}{l}{$\begin{array}{l}\text { Isolated cells } \\
(\%)\end{array}$} & $\begin{array}{l}\text { Small clusters } \\
(\%)\end{array}$ \\
\hline Insulin cells & & & \\
$\quad$ Control subjects & 4.1 & $(1.7-7.0)$ & $12.6(7.0-15.7)$ \\
Type 1 diabetes & 100 & & - \\
Type 2 diabetes & 3.7 & $(1.6-6.2)$ & $9.5(4.4-16.4)$ \\
Glucagon cells & & & \\
$\quad$ Control subjects & 3.8 & $(0.5-5.5)$ & $3.5(1.1-6.0)$ \\
Type 1 diabetes & 5.1 & $(1.2-8.0)$ & $6.9^{\mathrm{b}}(5.3-9.1)$ \\
Type 2 diabetes & $2.9(0.6-6.1)$ & $1.1^{\mathrm{a}}(0.0-2.2)$ \\
Somatostatin cells & & & \\
$\quad$ Control subjects & $4.3(0.6-7.2)$ & $5.9(0.0-10.0)$ \\
Type 1 diabetes & $15.5^{\mathrm{a}}(12.6-19.4)$ & $10.9(7.2-15.6)$ \\
Type 2 diabetes & 2.7 & $(1.1-4.8)$ & $3.1(0.8-9.6)$ \\
\hline
\end{tabular}

Results are expressed as mean with range in parentheses. ${ }^{a} p<0.005$ and ${ }^{b} p=0.01$ versus control subjects. Measurements were made in the region poor in PP cells. Nucleated cells isolated in ducts or in acini, or grouped in clusters of less than four cells were considered as being outside the islets

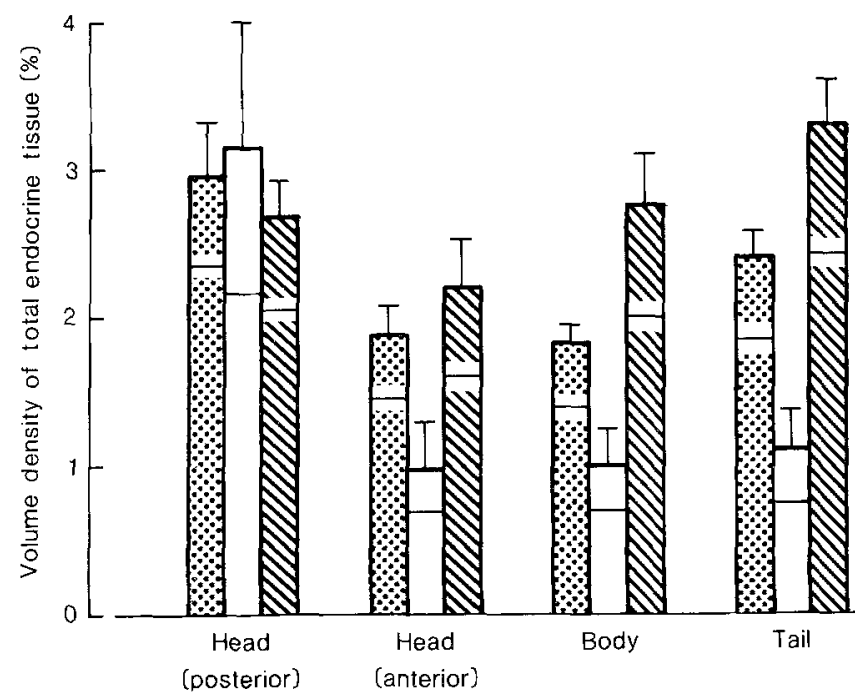

Fig. 1. Volume density of total endocrine tissue in four regions of the pancreas of control and diabetic subjects. Control subjects 8 ; Type 1 diabetic patients $\square$; Type 2 diabetic patients $\mathbb{N}$. The whole columns represent the mean volume density $( \pm$ SEM) in relation to epithelial tissue and the bars in the columns represent the mean volume density in relation to epithelial + mesenchymal tissue

of $B$ cells and non- $B$ cells at the periphery or along insular capillaries. In the Type 1 diabetic patients, the islets were smaller in size and were less easily seen because of poorly defined limits. They often displayed a ribbonlike pattern with $A$ and $D$ cells intermingled without particular organization. In the Type 2 diabetic patients, the general appearance of the islets was variable. Sometimes they were similar to control islets and sometimes they appeared markedly subdivided into lobules by fibrous septa or by deposits of amyloid substance. In the region rich in PP cells, many islets contained few B cells, even in normal subjects, and their architecture was often irregular. In the Type 1 diabetic patients, certain islets were composed almost exclusively of PP cells, showed a serpentine aspect and were in close contact with ductular structures.

Table 3 details the volume density of the four endocrine cell types in the three groups of subjects. In the Type 1 patients, the volume density of B cells was practically zero, that of A cells (in the PP-poor region) and D cells (in both regions) was increased by 1.5 -to twofold, and that of PP cells was unchanged. In Type 2 patients, the volume density of $\mathrm{B}, \mathrm{D}$ and PP cells was not significantly different from that measured in control subjects. The volume density of A cells was significantly $(p<$ $0.001)$ increased in the two lobes of the pancreas (Table 3).

The relative proportions of the four endocrine cell types in the different regions of the pancreas are shown in Figure 2. In the Type 1 patients, the disappearance of $B$ cells resulted in a marked increase in the proportion of A and D cells, at least in the regions poor in PP cells. On the other hand, the ratio of $\mathrm{D}$ to A cells did not differ from that found in control subjects (Table 4). In the lobe poor in PP cells of the Type 2 patients, the proportion of A cells increased $(p<0.001)$, that of B cells tended to decrease $(p=0.05)$ and that of $D$ cells was not significantly changed (Fig. 2). The ratio of A to B cells was markedly increased, whereas that of $D$ to $B$ cells was unchanged. The ratio of $\mathrm{D}$ to A cells was decreased by about $50 \%$ (Table 4 ).

The total mass of endocrine tissue averaged $1395 \mathrm{mg}$ in control subjects, $413 \mathrm{mg}$ in Type 1 and $1449 \mathrm{mg}$ in Type 2 patients. If the two lobes of the pancreas were considered separately, it could be calculated that, in Type 1 diabetes, the loss of total endocrine tissue reached $81 \pm 4.3 \%(p<0.01)$ in the lobe poor in PP cells and that the decrease of $10 \pm 28 \%$ was not significant in the lobe rich in PP cells. The calculated mass of each endocrine cell type in the pancreas of control and diabetic subjects is shown by Figure 3 . In the Type 1 diabetic patients, the mass of A, D and PP cells was not significantly different from that estimated for control subjects. It should be pointed out, however, that the highest value, for each cell type, was measured in the patient chronically treated with quinine. In the Type 2 diabetic subjects, the mass of B, D and PP cells was not modified; only one of the eight subjects had a mass of $D$ cells below the lowest control values. The mass of glucagon cells was increased compared with that in control subjects $(p=0.05)$.

\section{Discussion}

In the present study, patients classified as Type 1 diabetic subjects were completely dependent on exogenous insulin and had no measurable plasma $\mathrm{C}$-peptide. Their pancreases showed a marked atrophy almost limited to the lobe poor in PP cells [16], and a complete loss of B cells. In three of them, a few B cells could still be seen, 
Table 3. Volume density of insulin, glucagon, somatostatin and pancreatic polypeptide cells in relation to epithelial tissue

\begin{tabular}{|c|c|c|c|c|c|c|}
\hline & $\begin{array}{l}\text { Head (posterior) } \\
(\%)\end{array}$ & $\begin{array}{l}\text { Head (anterior) } \\
(\%)\end{array}$ & $\begin{array}{l}\text { Body } \\
(\%)\end{array}$ & & $\begin{array}{l}\text { Tail } \\
(\%)\end{array}$ & \\
\hline \multicolumn{7}{|l|}{ Insulin cells } \\
\hline Type 1 diabetic patients & $\ll 0.01$ & $\ll 0.01$ & $\ll 0.01$ & & $\ll 0.01$ & \\
\hline Type 2 diabetic patients & $0.64(0.28-1.44)$ & $1.43(0.64-2.36)$ & 1.72 & $(0.77-3.03)$ & 2.14 & $(1.57-3.35)$ \\
\hline \multicolumn{7}{|l|}{ Glucagon cells } \\
\hline Type 2 diabetic patients & $0.09(0.01-0.19)$ & $0.59(0.23-1.53)$ & 0.79 & $(0.50-1.16)$ & 0.90 & $(0.53-1.31)$ \\
\hline \multicolumn{7}{|l|}{ Somatostatin cells } \\
\hline Control subjects & $0.10(0.04-0.18)$ & $0.22(0.08-0.43)$ & 0.19 & $(0.07-0.30)$ & 0.15 & $(0.09-0.26)$ \\
\hline Type 1 diabetic patients & $0.24(0.06-0.46)$ & $0.39(0.10-0.85)$ & 0.33 & $(0.14-0.57)$ & 0.35 & $(0.12-0.80)$ \\
\hline Type 2 diabetic patients & $0.08(0.02-0.19)$ & $0.18(0.01-0.31)$ & 0.23 & $(0.02-0.34)$ & 0.22 & $(0.04-0.30)$ \\
\hline
\end{tabular}

Values are means with the ranges in parentheses

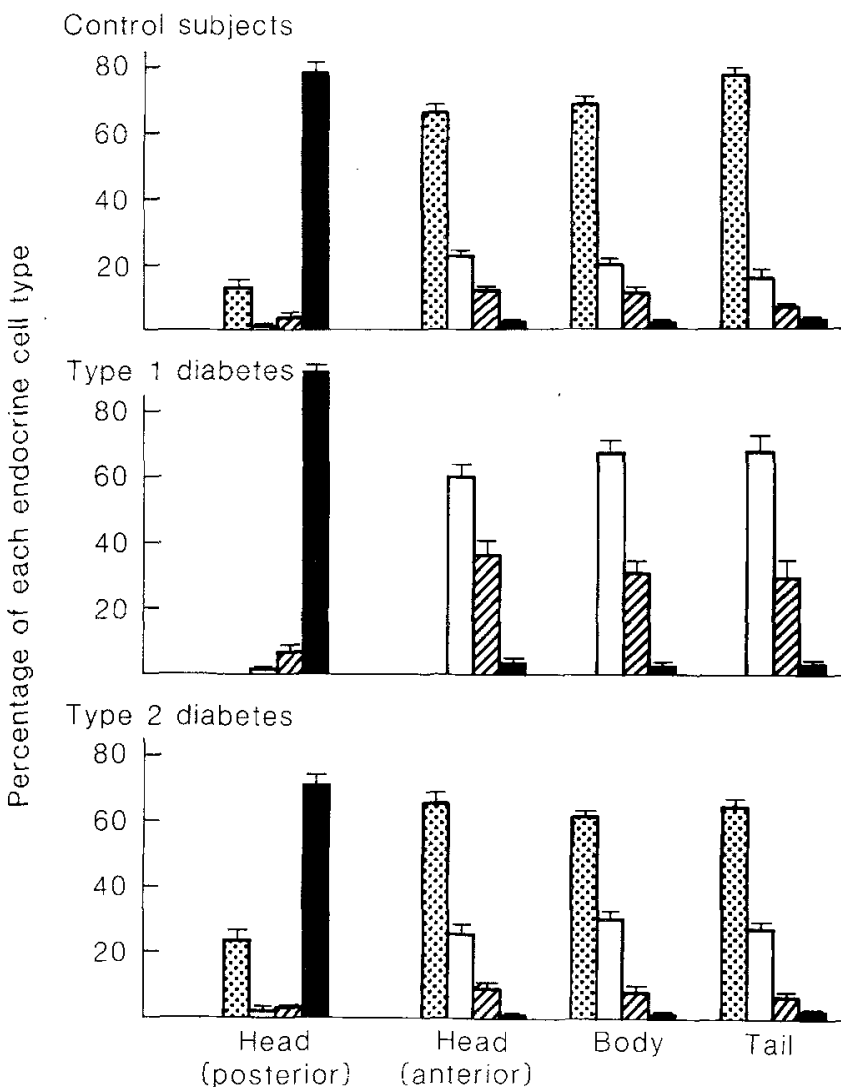

Fig. 2. Percentage of each endocrine cell type in four regions of the pancreas of control and diabetic subjects. B cells 8 A cells $\square$; D cells $\mathbb{Z}$; PP cells $\square$. Values are mean \pm SEM

always isolated between acinar cells. Their number (at the most seven per section) was incomparably lower than in many cases of 'juvenile-onset' diabetes studied earlier with histochemical $[2-5,22]$ or with immunocytochemical methods [12]. This discrepancy cannot be explained simply by differences in the duration of the disease, since our subjects had been diabetic for only 1.5 to 34 years. It more likely results from some heterogeneity of the material used in these larger earlier series.

This study confirms that the percentage of islet tissue is markedly reduced in the pancreas of Type 1 diabetic patients [2-5], but also shows that the decrease in volume density of the endocrine tissue occurs essentially in the lobe poor in PP cells. The proportion of B cells in the islets of the lobe rich in PP cells is too small for their disappearance to affect substantially the percentage of endocrine tissue in that region. It must also be emphasized that the volume density of endocrine tissue measured in a specimen of the lobe poor in PP cells does not permit adequate quantification of the changes occurring in Type 1 diabetes. Thus, the atrophy of the exocrine pancreas leads to underestimation of the atrophy of the endocrine tissue; the actual decrease in total endocrine cell mass in that region is as high as $81 \%$, whereas the average decrease in volume density is only $50 \%$. Our estimation agrees with the $75 \%$ decrease reported by others [23], but can hardly be compared with values published in earlier studies since the distinction between the two types of diabetes was not clearly made.

As previously reported $[10,12]$, the atrophic islets of the lobe poor in PP cells still contain numerous A and D cells. Their volume density was increased compared with the control subjects, again because of the atrophy of the exocrine tissue, but their total mass was instead slightly decreased. Disappearance of B cells caused dramatic changes in the relative proportions of the different islet cells, but the ratio of $\mathrm{D}$ to A cells was not altered. This suggests that the disappearance of insulin cells has no preferential influence on either of these two cell types. This does not imply that the interrelationships between $A$ and $D$ cells are insensitive to the marked architectural alterations of the islets. In this respect it is interesting to note that the proportion of isolated D cells is increased 3.5-fold in Type 1 diabetes. 
Table 4. Ratios of volume densities of A, B and D cells

\begin{tabular}{llll}
\hline & $\mathrm{A} / \mathrm{B}$ & $\mathrm{D} / \mathrm{B}$ & $\mathrm{D} / \mathrm{A}$ \\
\hline Control subjects & $0.26 \pm 0.02$ & $0.13 \pm 0.02$ & $0.55 \pm 0.08$ \\
Type 1 diabetic patients & - & - & $0.51 \pm 0.11$ \\
Type 2 diabetic patients & $0.43 \pm 0.03^{\mathrm{a}}$ & $0.12 \pm 0.02$ & $0.29 \pm 0.06^{\mathrm{b}}$ \\
\hline
\end{tabular}

Results are expressed as mean \pm SEM. ${ }^{\mathrm{a}} p<0.001,{ }^{\mathrm{b}} p<0.05$ versus control subjects. Comparisons were made between the average volume densities of each cell type in the three regions of the lobe poor in PP cells
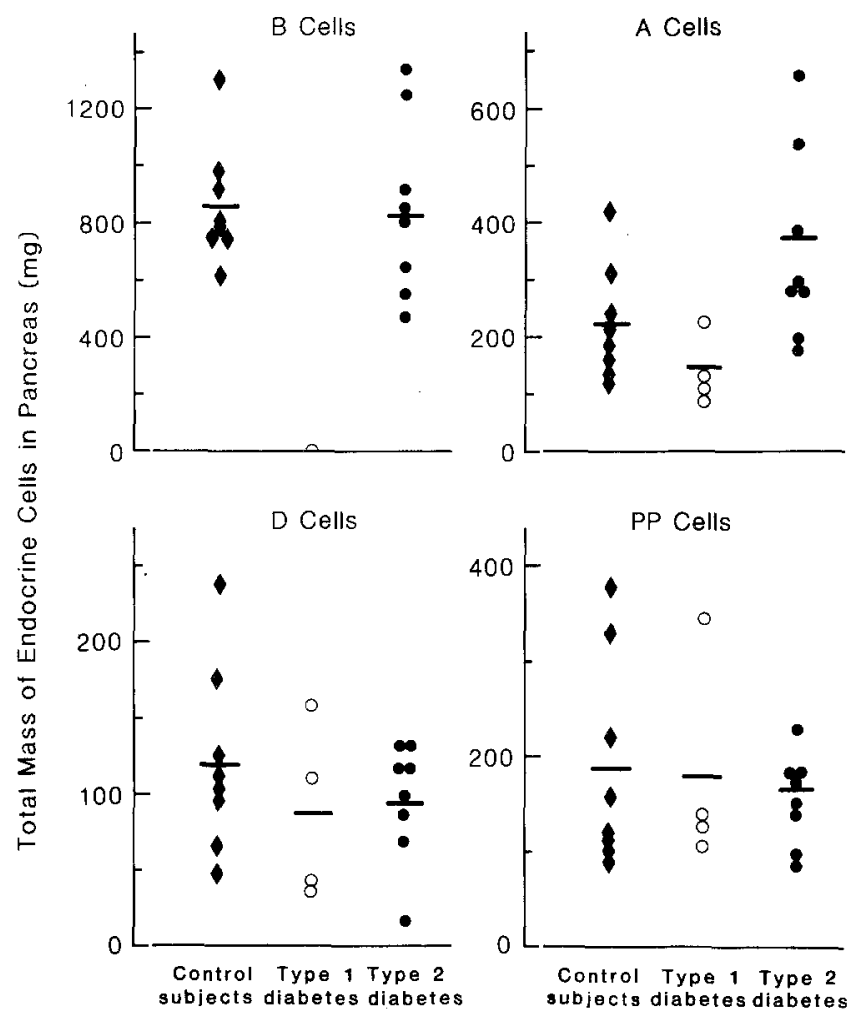

Fig.3. Estimated total mass of each endocrine cell type in the pancreas of control and diabetic subjects

Among the four Type 1 diabetic patients, the highest mass of A, D and PP cells was measured in the same subject. For many years this patient had been treated with quinine, a drug known to increase markedly the release of insulin in vitro [24]. It is possible that quinine also influences the other cell types of the endocrine pancreas. One cannot rule out, however, that the high mass of non- $B$ cells is due to a later onset of diabetes (46 years) than in the other patients ( $<15$ years).

Patients were classified as having Type 2 diabetes according to standard criteria [25]: All of them still had an important mass of B cells in their pancreas, even when control of their blood glucose appeared to require insulin therapy. This persistence of B cells is in agreement with the findings of numerous earlier studies using histochemical techniques [8,9].

It has been reported that the total mass of islet tissue is decreased in Type 2 diabetes. The extent of this change is difficult to evaluate from the studies of McLean and Ogilvie [2] and Gepts [4] since the distinction was not clearly made between the two types of diabetes. These authors acknowledged, however, that there is a considerable overlap between the figures obtained in patients with a 'diabetes of late onset' and in control subjects. Two more recent studies [23, 26], also using histochemical techniques, estimated the decrease in the mass of islet cells to about $40 \%$ in Type 2 diabetes. In the present series no significant change was found in either lobe of the pancreas. There may be several explanations for this discrepancy. First, our immunocytochemical technique is more sensitive and better able to detect poorly granulated cells, which may escape recognition by histochemical methods. Second, the populations of patients may be different. In one study [26], all diabetic patients had important amyloid deposits in their islets. Interestingly, the only two of our patients who had similar deposits exhibited an average decrease of $35 \%$ in the mass of total endocrine tissue in the lobe poor in PP cells.

There appears to be general agreement between all but one study [23], that the relative proportions of $B$ and A cells are altered in Type 2 diabetes $[8,9]$. We confirm here that the ratio of $\mathrm{A}$ to $\mathrm{B}$ cells is increased and that this modification is due to an absolute increase in the mass of A cells. The suggestion [27] that the proportion of somatostatin cells is increased in Type 2 diabetes is not borne out by the present data, which show that the ratio of $B$ to $D$ cells and the total mass of $D$ cells are not different from those found in control subjects. It is also striking that the proportion of isolated D cells is not increased as in Type 1 diabetes.

Finally, the present findings may have several physiopathological implications: (1) From morphometrical studies showing a decrease of $\mathrm{D}$ cells in hyperinsulinaemic diabetic mice [28], it was inferred that the elevation of circulating glucagon levels in Type 2 diabetes could result from a somatostatin deficiency [29]. Our data do indeed reveal a marked decrease in the ratio of $\mathrm{D}$ to $\mathrm{A}$ cells, which, however, is due to an absolute increase in the mass of A cells rather than to a decrease in the mass of D cells. (2) The lack of changes in the mass of D and A cells and the normal D to A cell ratio in the Type 1 diabetic patients are in keeping with the hypothesis [30] that the hyperglucagonaemia found in these patients results from an intra-islet insulin deficiency. (3) Alterations in the circulating levels of somatostatin or pancreatic-polypeptide in either type of diabetes cannot be ascribed to changes in the mass of D or PP cells. (4) The marked hyperplasia of $D$ cells in animals made diabetic with streptozotocin [10] is an important characteristic that distinguishes the animal model from human Type 1 diabetes.

Acknowledgements. We are grateful to Professor J. Haot for continuous support. We thank Miss D. Godichal for editorial help. J.C.H. is 'Chercheur Qualifié' of the FNRS, Brussels. This study was supported by Grant 3.4560.81 from the FRSM, Brussels. 


\section{References}

1. Ferner H (1942) Beiträge zur Histobiologie der Langerhansschen Inseln des Menschen mit besonderer Berücksichtigung der Silberzellen und ihrer Beziehung zum Pankreasdiabetes. Virchows Arch 309: 87-136

2. Maclean N, Ogilvie RF (1955) Quantitative estimation of the pancreatic islet tissue in diabetic subjects. Diabetes 4:367-376

3. Maclean N, Ogilvie RF (1959) Observations on the pancreatic islet tissue of young diabetic subjects. Diabetes $8: 83-91$

4. Gepts W (1958) Die histopathologischen Veränderungen der Langerhansschen Inseln und ihre Bedeutung in der Frage der Pathogenese des menschlichen Diabetes. Endokrinologie 36: 185-211

5. Gepts W (1965) Pathologic anatomy of the pancreas in juvenile diabetes mellitus. Diabetes 14: 619-633

6. Creutzfeldt W, Theodossiou A (1957) Die Relation der A- und BZellen in den Pankreasinseln bei Nichtdiabetikern und Diabetikern. Beitr Path Anat 117: 235-252

7. Seifert G (1959) Die pathologische morphologie der Langerhansschen inseln, besonders beim diabetes mellitus des menschen. Verb Dtsch Ges Pathol 18: 50-84

8. Volk BW, Wellman KF (1977) Idiopathic diabetes. In: Volk BW, Wellman KF (eds) The diabetic pancreas. Baillière Tindall, London, pp 231-260

9. Gepts W, Lecompte PM (1981) The pancreatic islets in diabetes. Am J Med 70: 105-115

10. Orci L, Baetens D, Rufener C, Amherdt M, Ravazzola M, Studer P, Malaisse-Lagae F, Unger RH (1976) Hypertrophy and hyperplasia of somatostatin-containing D-cells in diabetes. Proc Natl Acad Sci 73: 1338-1342

11. Gepts W, De Mey J, Marichal-Pipeleers M (1977) Pancreatic polypeptide cells in the pancreas of juvenile diabetics. Diabetologia 13:27-34

12. Gepts W, De Mey J (1978) Islet cell survival determined by morphology. An immunocytochemical study of the islets of Langerhans in juvenile diabetes mellitus. Diabetes 27 (Suppl 1): 251-261

13. Orci L, Baetens D, Ravazzola M, Stefan Y, Malaisse-Lagae F (1976) Pancreatic polypeptide and glucagon: non-random distribution in pancreatic islets. Life Sci 19: 1811-1816

14. Malaisse-Lagae F, Stefan Y, Cox J, Perrelet A, Orci L (1979) Identification of a lobe in the adult human pancreas rich in pancreatic polypeptide. Diabetologia 17: 361-365

15. Rahier J, Wallon J, Gepts W, Haot J (1979) Localization of pancreatic polypeptide cells in a limited lobe of the human neonate pancreas: remnant of the ventral primordium? Cell Tissue Res 200: $359-366$

16. Rahier J, Wallon J, Gepts W (1981) Volume of the pancreatic polypeptide cell rich lobe in the diabetic pancreas. Diabetologia 21: 318-319 (Abstract)

17. Sternberger LR (1979) Immunocytochemistry, 2nd edn. John Wiley \& Sons, New York

18. Chalkley HW (1943) Method for the quantitative morphologic analysis of tissues. J Natl Cancer Inst 4: 47-53

19. Rahier J, Wallon J, Henquin JC (1981) Cell populations in the endocrine pancreas of human neonates and infants. Diabetologia 20: $540-546$

20. Weibel ER (1973) Stereological techniques for electron microscopic morphometry. In: Hayat MA (ed) Principles and techniques of electron microscopy. Van Nostrand Reinhold, New York, pp 239-296

21. Snedecor GW, Cochran WG (1967) Statistical methods. 6th edition. The Iowa State University Press. Ames, Iowa USA

22. Doniach I, Morgan AG (1973) Islets of Langerhans in juvenile diabetes mellitus. Clin Endocrinol 2: 233-248

23. Saito K, Yaginuma N, Takahashi T (1979) Differential volumetry of $A, B$ and $D$ cells in the pancreatic islets of diabetic and non diabetic subjects. Tohoku J Exp Med 129: 273-283

24. Henquin JC, Horemans B, Nenquin $M$, Verniers $J$, Lambert AE (1975) Quinine-induced modifications of insulin release and glucose metabolism by isolated pancreatic islets. FEBS Lett 57: $280-284$

25. National Diabetes Data Group (1979) Classification of diabetes mellitus and other categories of glucose intolerance. Diabetes 28 : 1039-1057

26. Westermark P, Wilander E (1978) The influence of amyloid deposits on the islet volume in maturity onset diabetes mellitus. Diabetologia 15: 417-421

27. Fujita T (1966) D-zellen der Pankreasinseln beim Diabetes Mellitus mit besonderer Berücksichtigung ihrer Argyrophilie. Z Zellforsch $69: 363-370$

28. Baetens D, Stefan Y, Ravazzola M, Malaisse-Lagae F, Coleman DL, Orci L (1978) Alteration of islet cell populations in spontaneously diabetic mice. Diabetes $27: 1-7$

29. Unger RH, Orci L (1977) Possible roles of the pancreatic D-cell in the normal and diabetic states. Diabetes 26: 241-244

30. Weir GC, Knowlton SD, Atkins RF, McKennan KX, Martin DB (1976) Glucagon secretion from the perfused pancreas of streptozotocin-treated rats. Diabetes 25: 275-282

Received: 14 July 1982

and in revised form: 5 October 1982

Dr. J. Rahier

Department of Pathology

University Hospital St. Luc

Avenue Hippocrate 10

B-1200 Brussels, Belgium

Note added in proof: Since the submission of this manuscript, two studies on the same subject have been published in complete form ( $Y$. Stefan et al., 1982 Diabetes 31: 694-700) or in abstract form (G. Klöppel et al., 1982 Diabetologia 23: 180). 